\title{
Research on Human Resource Recruitment Management of Inspection \& Certification Institution Based on Game Theory
}

\author{
Qingfang Liu ${ }^{1}$, Yixian Wang ${ }^{1}$, Zhaoying Zuo ${ }^{1,2}$, a, ", Wenju Tian ${ }^{1}$, Yan Zhang ${ }^{1}$, \\ Qiuyun Lin ${ }^{1}$, Shangrui $\mathrm{Wu}^{1}$ \\ ${ }^{1}$ Rizhao Inspection\&certification Company, Rizhao, 276800 China; \\ ${ }^{2}$ Business School, Hohai University. Nanjing, 211100 China. \\ ",a zuozhaoying0531@sina.com
}

Keywords: inspection and certification; human resource management; game theory.

\begin{abstract}
The staff is the strategic resource of the inspection and certification institutions, and human resource management has become the key factors which inspection and certification institutions obtain and maintain the competitive advantage. Through the game equilibrium analysis of the internal and external recruitment mode of the inspection and certification institutions, this paper defines the conditions for employers and applicants to take their own optimal decision. There is of great value to improve the human resource management level of China's inspection and certification institutions.
\end{abstract}

\section{Introduction}

The survey results of "2017 China's Foreign Trade Service Market Research Report" show that in rankings of the most reliable inspection and certification institutions of foreign trade inspection and certification in 2017, the Swiss SGS continue at the top in this list and dominated the top for long, the second is Germany TÜV Rhineland Group, American UL and UK Intertie Group, native China quality certification center only ranks sixth. According to the repot of "Economic Information Daily" on October 10, 2017, more and more countries or receiving traders require foreign capital inspection and certification institutions to provide relevant certificates and even as exchange settlement voucher, export commodity inspection and certification market has been monopolized by foreign institutions to a certain extent, according to the survey of Ningbo certification and accreditation association, foreign institutions occupy more than $85 \%$ of market share in Ningbo import and export inspection and certification. Certification and Accreditation Administration of the People's Republic of China reported on September 11, 2017, 25 registry staff renewed verification experience in one Shanghai certification institution, including the company's major shareholders; defrauded the qualifications of the registry staff, rampant degree was horrifying. By the end of 2016, China's totally issued more than 1.768 million effective authentication certificate, more than 597000 inspection and certification institutions, rank the world's first for many years, the total revenue of inspection and certification services business reached 200 billion Yuan, and become the world's fastest growing inspection certification market. Inspection and certification industry is the high technology services which state encourages the development, 2016 "13th five-year plan" national strategic emerging industry development planning listed the certification industry in the national strategic emerging industry, and certification and accreditation is an important part of national quality infrastructure (NQI). The staff is the strategic resource of the inspection and certification institutions, and human resource management has become the key factor for inspection and certification institutions obtain and maintain the competitive advantage. When human resource managers try to find the most suitable talents, the selection and operation of recruitment channels are very important. In this context, it is of great significance to study the recruitment management of human resources of inspection and certification institutions. 


\section{Overview of Domestic and Foreign Research}

Research on inspection and certification institutions. Liu R., Cui L., Zeng G.et al. (2014) applying the fuzzy Seroquel method to measure the service quality in certification and inspection industry. Deaton, (2004) analyzed the nature of third-party certification intermediaries and believed that the validity of certification depends on the independence of the water quality inspection bodies and the objectivity of the certification process and that the heavy independence. Of the certification bodies' income on enterprises will increase the risks of certification collusion. (Zoo et al., 2017) discussed the strategy of inspection industry of China to improve the effective of quality management system. (Zoo and Tang, 2017) research the influence of the certifications on the enterprise performance.

Game theory is the study of mathematical models of conflict and cooperation between intelligent rational decision-makers". The game theory model consists of three components: player, strategy, and pay-off. The player is an agent who participates in the game and each player has his own strategies with different pay-offs. With this basic setting, the main purpose of game theory is to derive equilibrium in the game depending on the players and their strategies.Chen\&Jiang, (2017) established a supply chain enterprises operating mechanism model from the perspective of game theory, used repeated game, individual game and group of evolutionary game and verified the importance of cooperation in creative products supply chain through theoretical proof and examples. Kim et al., (2017) proposed a new standardization framework by combining network analysis and the game theory model. Zhang Yet al...(2017) researches national supervision on inspection body by game theory.

\section{Model of Recruitment}

The recruitment of inspection and certification institutions generally comes from the following purposes: Firstly, nowadays, the total supply of human resources cannot meet the general objectives of enterprises or positions, i.e., total planned business volume or total planned output. Secondly, the job vacancy caused by the normal replacement of the mobile personnel in the enterprise or the various posts; Thirdly, the possible demand for human resources by the changes in the production technology level or management mode of the enterprises or various posts; Fourthly, to meet the needs of the personnel required for new planning or new business. Suppose that the inspection and certification institutions determine the future earnings of the recruiter to be R; the sum of costs and expenses paid by the inspection and certification institutions in staff recruitment process is $\mathrm{C} 1$; the added income after the applicant has been hired is $\mathrm{V}$; if not employed or not participate in recruitment, the added income is 0 ; the cost that the individual spend in recruitment process is $\mathrm{C} 2$;

The benefit matrix for both parties is shown in table 1 .

Table. 1 Mutual game matrix of internal recruitment

\begin{tabular}{c|c|c}
\hline & apply & No apply \\
\hline employment & R-C $1-\mathrm{V}, \mathrm{V}-\mathrm{C}_{2}$ & $-\mathrm{C}_{1}, 0$ \\
\hline without employment & $0,-\mathrm{C}_{2}$ & 0,0 \\
\hline
\end{tabular}

$\mathrm{P} 1$ represents the employment probability of employment unit, and P2 represents the probability that the applicants participate in recruitment.

First of all, given $\mathrm{P}$, the expected benefits that the employment units choose to employ or and not to employ, respectively:

By formula (2.1) and (2.2)

$$
\begin{gathered}
\mathrm{U} 1(1, \mathrm{P} 1)=-\mathrm{C} \times(1-\mathrm{P} 1)+(\mathrm{R}-\mathrm{C} 1-\mathrm{V}) \times \mathrm{P} 2) \\
\mathrm{U} 2(0, \mathrm{P} 2)=0 \times(1-\mathrm{P} 2)+0 \times \mathrm{P} 2
\end{gathered}
$$

$$
\mathrm{P} 2 *=\mathrm{C} 1 /(\mathrm{R}-\mathrm{V})
$$

If the probability which employed staff participate in recruitment is less than $\mathrm{C} 1 /(\mathrm{R}-\mathrm{V})$, then the strategy of inspection and certification institutions is not to carry out employment work. If the probability of participation in recruitment is greater than $\mathrm{C} 1 /(\mathrm{R}-\mathrm{V})$, then the strategy of the inspection and certification institutions is to carry out the employment work. 
Secondly, given P2, the expected benefits that the applicants choose participate or not participate in the recruitment, respectively:

By formula (2.4) and (2.5)

$$
\begin{gathered}
\mathrm{U} 3(\mathrm{P} 1,1)=(\mathrm{V}-\mathrm{C} 2) \times \mathrm{P} 1+(-\mathrm{C} 2) \times(1-\mathrm{P} 1) \\
\mathrm{U} 4(\mathrm{P} 1,0)=0 \times \mathrm{P} 1+0 \times(1-\mathrm{P} 1)
\end{gathered}
$$

$$
\mathrm{P} 1 *=\mathrm{C} 2 / \mathrm{V}
$$

If the employment probability of inspection and certification institutions is less than $\mathrm{C} 2 / \mathrm{V}$, then the optimal choice for the applicants is not to participate in recruitment. If the employment probability of inspection and certification institutions is greater than $\mathrm{C} 2 / \mathrm{V}$, the optimal choice for the applicants is to participate in recruitment.

It is thus clear that the Nash equilibrium of internal recruitment is shown as $\mathrm{C} 1 /(\mathrm{R}-\mathrm{V}), \mathrm{P} 1 *=\mathrm{C} 2$ / V.

Through the game equilibrium analysis of internal and external recruitment modes, it is clear that both sides define the optimal decision under which condition. Namely, when the inspection and certification institutions adopt the internal recruitment, they can decide whether to carry out the employment work according to the probability that employed staff participate in recruitment; when the inspection and certification institutions adopt external recruitment, they can predict which level of applicants will sign with the inspection and certification institutions according to the types of the applicants. Thus achieving the recruitment goal of "low cost and high benefit", promotes the best human resource management, and realizes the effective improvement of the core competitiveness of the units.

$\mathrm{C} 3$ is the recruitment conditions provided by the employers, such as working conditions and salary, etc. Suppose that the hire condition $\mathrm{C} 3$ can be measured by money; the quality of excellent talents is $A 1$, while the quality of ordinary talents is $A 2$, among them, $A 1>A 2>0, A \in\{A 2, A 1\}$. At the same time, it is assumed that probability $\pi$ in the existing talents chooses $A 1$, then $1-\pi$, choose $A 2$. The benefit vector $(0,0)$ represents the status, the employers provide the recruitment conditions and the talent has the ability to create value, and the benefit function is.

$$
\begin{aligned}
\text { Benefit of employers } \mathrm{U} 5 & =\mathrm{A}-\mathrm{C} 3 \\
\text { Applicant's benefits U6 } & =\mathrm{C} 3-\mathrm{A}
\end{aligned}
$$

If the employers can judge the talent ability at the time of recruitment, then the equilibrium condition is highly competent people $\mathrm{C} 3^{\prime}=\mathrm{A} 1$, and the low competent people $\mathrm{C} 3^{\prime}=\mathrm{A} 2$. But in fact, because employers can't know the exact types of the applicants' quality, so the employers will hire two types of talents indiscriminately. When recruited a certain number of people, it is impossible to predict the size of their contribution to the employers because they are unable to understand the staff quality, so can only provide the same recruitment conditions for them, set $\mathrm{C} 3=\pi$, PI A1+ $(1-\pi) \mathrm{A} 2$, through this formula, C3" < C3 < C3'. In actual talent recruitment market, there are all sorts of applicants with high or low quality, and employers often determine recruitment conditions according to the average level, Only talents with ordinary quality accept the jobs, excellent talents will reject. In this way, the employers can only recruit ordinary talents, and the benefit will not exceed the amount of A1. Therefore, all the people which sign with recruited parties in the equilibrium are all ordinary talents.

Table. 2 Game matrix of mutual external recruiters

\begin{tabular}{c|c|c}
\hline & hire & No hire \\
\hline high quality & $\mathrm{A}_{1}-\mathrm{C}_{3}{ }^{\prime}, \mathrm{C}_{3}{ }^{\prime}-\mathrm{A}_{1}$ & $-\mathrm{C}_{3}{ }^{\prime}, 0$ \\
\hline low quality & $\mathrm{A}_{2}-\mathrm{C}_{3}{ }^{\prime}, \mathrm{C}_{3}{ }^{\prime}-\mathrm{A}_{2}$ & $-\mathrm{C}_{3}{ }^{\prime}, 0$ \\
\hline
\end{tabular}

\section{Conclusion}

Through internal recruitment, we should select appropriate personnel to supplement activities in vacancies or new posts from human resource reserves. Advantages are high accuracy, fast adaptation, 
strong incentive and low cost. The characteristics of external recruitment are bringing new ideas and new methods, helping to recruit first-class talents, establishing image effect. Through the game equilibrium analysis of the internal and external recruitment mode of the inspection and certification institutions, it is defined that employers and the applicants take own optimal decision under what conditions. Namely, when the inspection and certification institutions adopt the internal recruitment, they can decide whether to employ the applicants according to the probability which employed staff participate in recruitment; when the inspection and certification institutions adopt external recruitment, it can predict which level of applicants will be signed with the inspection and certification institutions according to the types of the applicants. Thus achieving the goal of "low cost and high benefit", and promote the best human resource management, the core competitiveness of China's inspection and certification institutions can be effectively improved. Subsequently. In the future, the research on performance management of training and selection can be carried out.

\section{References}

[1]. Zhang Y., Wang Y., Zuo Z. et al.,Research on the Evolution Game of National Supervision on Inspection Body, Revista de la Facultad de Ingeniería,2017,32(8),182-188.

[2]. Zoo Z.,Tang D., Research on the Impact of ISO9001 Certification Effectiveness on Organizational Performance in China, Boletin tecnico/Technical Bulletin,2017, 55(4), 644-655.

[3]. Liu R., Cui L., Zeng G., Wu H., Wang C., Yan S. Applying the fuzzy servqual method to measure the service quality in certification and inspection industry, Applied Soft Computing Journal, 2014, 26, 508-512.

[4]. Deaton B.J. A theoretical framework for examining the role of third-party certifiers, Food Control, 2004, 15, (8): 615-619.

[5]. Tortorella G L, Marian G A, Fogliatto F S, et al. Learning organisation and human resources management practices: an exploratory research in medium-sized enterprises undergoing a lean implementation [J]. International Journal of Production Research, 2015, 53(13):3989-4000.

[6]. Ceram, M. The role of human resources in facilitating management integration in the process of a post-merger integration[J]. Journal of Chromatography A, 2015, 922(1):1-11.

[7]. Chen T., Jiang Y...Research on operating mechanism for creative products supply chain based on game theory, Discrete and Continuous Dynamical Systems - Series S (DCDS-S), 2017. 8( 6) 1103-1112.

[8]. Kim K., Jung S., Hwang J., and Hong A. A dynamic framework for analyzing technology standardisation using network analysis and game theory, Technology Analysis and Strategic Management, 2017.394. 1-16.

[9]. Zoo Z., Sun J., Chang Z.et al. Research on Development Strategy of Chinas Certification Industry, Revisit de la Faulted de Ingénueía, 2017,32(14),894-898. 